\title{
HUBUNGAN KETERAMPILAN SOSIAL DAN PENGGUNAAN GADGET SMARTPHONE DENGAN PRESTASI BELAJAR SISWA SMA NEGERI 9 MALANG
}

\author{
Tania Clara Dewanti, Widada, Triyono \\ Bimbingan dan Konseling-Fakultas Ilmu Pendidikan-Universitas Negeri Malang-Jl.Semarang No. 5 Malang \\ E-mail: taniaclaradewanti@gmail.com
}

\begin{abstract}
Technology development in this era has progressing very rapidly, marked by the progress in information aspect and technology. One form of the technology development is a smart phone gadget. Gadget smart phone has a negative impact and positive impact on social skills and student achievement. This research intend to get know the correlation between social skills and use of smart phone with student achievement. The design of study is a descriptive correlation research on the subject with amounted 84 students. The used instruments are social skills scale and use of gadget smart phone scale with the number 77 items. The test done to the 40 people and generate validity of 0,312 and reliability of 0,929 and 0,912 . The result of research shows a correlation of $\mathrm{R}=0.769, \mathrm{p}=0.000<0.05$ means that there is a relationship between social skills and use your smart phone gadget with student achievement SMA Negeri 9 Malang.
\end{abstract}

Keywords: social skills; gadget smart phone; academic achievement

\begin{abstract}
Abstrak: Perkembangan teknologi pada zaman sekarang mengalami kemajuan yang sangat pesat, ditandai dengan kemajuan pada bidang informasi dan teknologi. Salah satu wujud perkembangan teknologi yang mengalami kemajuan sangat pesat merupakan gadget smartphone. Gadget smartphone memiliki dampak negatif dan dampak positif bagi keterampilan sosial dan prestasi belajar siswa. Penelitian ini bertujuan untuk mengetahui hubungan keterampilan sosial dan penggunaan gadget smartphone dengan prestasi belajar. Rancangan penelitian yang digunakan adalah deskriptif korelasional pada subyek penelitian yang berjumlah 84 siswa. Instrumen yang digunakan adalah skala keterampilan sosial dan skala penggunaan gadget smartphone dengan jumlah 77 butir. Uji coba dilakukan kepada 40 orang yang menghasilkan validitas butir sebesar 0,312 serta reliabilitas sebesar 0,929 dan 0,912. Hasil uji penelitian menunjukkan korelasi sebesar $\mathrm{R}=0,769, p=0,000<0,05$ artinya ada hubungan antara keterampilan sosial dan penggunaan gadget smartphone dengan prestasi belajar siswa SMA Negeri 9 Malang.
\end{abstract}

Kata kunci: keterampilan sosial; gadget smartphone; prestasi belajar 
Perkembangan teknologi pada zaman sekarang mengalami kemajuan yang sangat pesat, ditandai dengan kemajuan pada bidang informasi dan teknologi. Indonesia merupakan salah satu negara yang turut serta dalam kemajuan teknologi dan informasi tersebut (Ameliola \& Nugraha, 2013). Menurut Indrawan (2014) gadget adalah sebuah istilah yang berasal dari bahasa Inggris yang merujuk pada perangkat elektronik kecil yang memiliki fungsi khusus untuk mengunduh informasi-informasi terbaru dengan berbagai teknologi maupun fitur terbaru, sehingga membuat hidup manusia menjadi lebih praktis. Saat ini tidak sedikit remaja sudah menggunakan gadget yang berisi aplikasi atau software yang beberapa isinya diciptakan khusus untuk kalangan orang tua dan dewasa (Isna, 2012). Hal tersebut berdampak pada proses tumbuh kembang, baik secara sosial dan emosional, sebab individu pada usia remaja identik dengan rasa ingin tahu yang besar dengan kontrol terhadap perilaku adaptif yang rendah (Widyastuti, 2009). Berbagai dampak yang ditimbulkan akibat kurangnya kontrol terhadap penggunaan gadget pada remaja ialah tingkat prestasi belajar dan keterampilan dalam berperilaku sosial (Blais, 2007). Menurut Blais (2007) penggunaan gadget pada remaja salah satunya berdampak pada kemampuannya untuk bersosialisasi dengan baik dalam lingkungan keluarga maupun lingkungan pergaulan di masyarakat.

Violence \& Gore (dalam Mubarok, 2013) yang menyatakan bahwa Antisocial Behaviour merupakan dampak negatif gadget yang disebabkan karena penyalahgunaan gadget itu sendiri. Hal ini terjadi di mana ketika seseorang merasa gadget merupakan satu-satunya hal yang paling penting dalam hidupnya, sehingga ia melupakan keadaan di sekitarnya. Akan muncul ketidakpedulian dalam dirinya terhadap lingkungannya. Satu-satunya hal yang dapat menarik perhatiannya hanyalah gadget yang ia gunakan. Akibat yang timbul ialah dia menjadi jarang berinteraksi dengan orangorang yang berada di lingkungan sekitarnya, sehingga dia akan kesulitan untuk bersosialisasi dan menjalin relasi dengan orang-orang di sekitarnya.

Berdasarkan berbagai ulasan diatas dan hasil observasi serta interview terhadap konselor di SMA Negeri 9 Malang, 80\% dari jumlah keseluruhan adalah 967 siswa sudah memiliki gadget. Penelitian ini bertujuan untuk mengetahui hubungan antara keterampilan sosial dan penggunaan gadget terhadap pretasi belajar siswa SMA Negeri 9 Malang.

\section{METODE}

Desain penelitian yang digunakan adalah korelasional. Subyek penelitian adalah siswa SMA Negeri 9 Malang sebanyak 84 subyek yang terdiri dari kelas X A1 sebanyak 30 siswa, siswa kelas X C1 sebanyak 24 siswa, dan siswa kelas X G1 sebanyak 30 siswa.

Instrumen penelitian terdiri dari skala keterampilan sosial dan skala penggunaan gadget smartphone. Masing-masing skala terdapat 77 butir. Jabaran variabel skala tayangan erotika dan perilaku seksual dapat dilihat pada tabel 1, sedangkan Jabaran Variabel Skala Penggunaan Gadget Smartphone dapat dilihat pada tabel 2.

Adapun prosedur pengolahan data yang dilakukan melalui tahap pengecekan, penyeleksian, dan skoring. Data dianalisis dengan teknik deskriptif dan korelasional. Uji validitas ini dilakukan dengan menggunakan rumus korelasi product moment dari Person yaitu dengan mengkorelasikan antara skor butir pada setiap item dengan skor total. Butir pernyataan dinyatakan valid apabila memiliki nilai koefisien korelasi lebih dari $\mathrm{r}$ tabel Pearson $(\mathrm{N}=40$ Sig. $0,05=0,312)$ dan memiliki nilai signifikansi kurang dari 0,05 atau taraf kepercayaan 95\%. Reliabilitas instrument sebesar 0,929 dan 0,912.

Berdasarkan hasil uji validitas skala keterampilan sosial diketahui bahwa dari 50 butir, didapatkan 44 butir valid dan 6 butir yang tidak valid. Pada skala penggunaan gadget smartphone diketahui bahwa dari 27 butir, didapatkan 24 butir valid dan 3 butir tidak valid. 
Tabel 1: Jabaran Variabel Skala Keterampilan Sosial

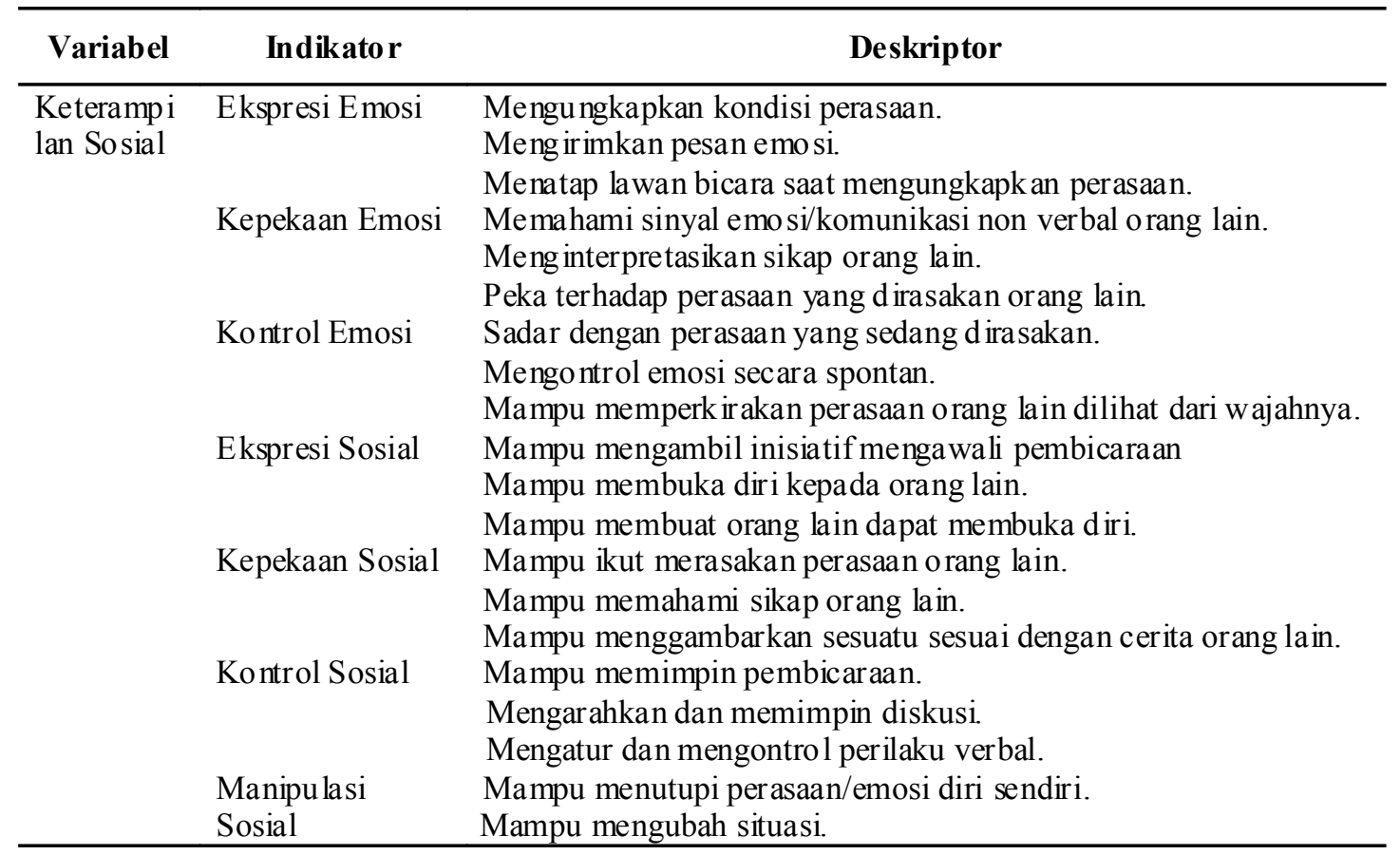

\section{HASIL}

Berdasarkan hasil penelitian, keterampilan sosial yang dideskripsikan menjadi 4 tingkatan, yaitu tingkat sangat tinggi, tinggi, sedang, dan rendah disajikan pada tabel 1. Penggunaan gadget smartphone dideskripsikan menjadi 4 tingkatan, yaitu sangat tinggi, tinggi, sedang, dan rendah yang disajikan dan disajikan pada tabel 2. Prestasi Belajar dideskripsikan menjadi 4 tingkatan, yaitu sangat berprestasi, berprestasi, cukup berpretasi, dan tidak berprsetasi yang disajikan pada tabel 3 .

Uji asumsi klasik pada penelitian ini dilakukan dengan dua cara yaitu uji normalitas dan uji linieritas. Hasil uji normalitas data dinyatakan normal yaitu pada keterampilan sosial dengan prestasi belajar (sig $0,906>0,05)$ dan skala penggunaan gadget smartphone dengan prestasi belajar (sig 0,885 $>0,05)$.

Hasil uji linieritas didapatkan pada keterampilan sosial dengan prestasi belajar ( $\mathrm{F}=40,468 \mathrm{Sig}$. $0,000<0,05)$ dan skala penggunaan gadget smartphone dengan prestasi belajar $(\mathrm{F}=49,342$ Sig. $0,000<0,05)$ maka dapat disimpulkan bahwa hubungan antara keterampilan sosial dan penggunaan gadget smartphone dengan prestasi belajar berdistribusi linier.

Hasil analisis Product Moment Pearson menunjukkan koefisien korelasi sebesar R =0,769 $\mathrm{p}=$ $0,000<0,05$. Hal ini berarti $\mathrm{H}_{1}$ diterima dengan kesimpulan ada hubungan antara keterampilan sosial dan penggunaan gadget smartphone dengan prestasi belajar siswa SMA Negeri 9 Malang.

\section{PEMBAHASAN}

\section{Hubungan antara Keterampilan Sosial dan Penggunaan Gadget Smartphone dengan Prestasi Belajar Siswa SMA Negeri 9 Malang}

Dari hasil penelitian yang telah dilakukan dan dianalisa, menunjukan adanya hubungan antara keterampilan sosial dan penggunaan gadget smartphone dengan prestasi belajar siswa SMA Negeri 9 Malang. Hal ini dapat ditunjukan dengan nilai signifikansi yang didapat dari hasil análisis korelasi ganda sebesar $0,000 \mathrm{~d} " 0,05$. 
Dewanti, Widada, Triyono, Hubungan Keterampilan Sosial... | 129

Tabel 2: Jabaran Variabel Skala Penggunaan Gadget Smartphone

\begin{tabular}{lll}
\hline \multicolumn{1}{c}{ Variabel } & \multicolumn{1}{c}{ Indikator } & \multicolumn{1}{c}{ Deskriptor } \\
\hline $\begin{array}{l}\text { Pemanfaatan } \\
\text { Gadget }\end{array}$ & Mengetahui Fungsi dan jenis ap likasi & Mengerti fung si dari smartphone \\
Smartphone & smartphone & $\begin{array}{l}\text { Mengetahui aplikasi internet dan } \\
\text { fungsinya }\end{array}$ \\
& Mampu mengoprasikan smartphone. & $\begin{array}{l}\text { Mampu mengoperasikan smartphone } \\
\text { untuk mengu mpu lkan informasi }\end{array}$ \\
& & Keuntungan pemanfaatan smartphone. \\
& Memanfaatkan fungsi dan aplikasi yang & Memanfaatkan fungsi smartphone \\
& ada pada smartphone & Frekuensi pemanfaatan smartphone \\
\hline
\end{tabular}

Tabel 3: Distribusi Frekuensi Prestasi Belajar

\begin{tabular}{cccc}
\hline Kategori & Frekuensi & Presentase & Klasifikasi \\
\hline Sangat berprestasi & 46 & $54 \%$ & Sangat banyak \\
Berprestasi & 38 & $45 \%$ & Banyak \\
Cukup berprestasi & 0 & $0 \%$ & \\
Tidak berprestasi & 0 & $0 \%$ & \\
Jumlah & 84 & $100 \%$ & \\
\hline
\end{tabular}

Keterampilan sosial secara positifmenjadikan seseorang memiliki emosi yang baik yang diwujudkan kedalam bentuk interaksi komunikasi yang positif dengan orang lain. Merujuk pada hal tersebut, siswa dengan keterampilan sosial yang tinggi maka mempunyai potensi untuk melakukan kegiatan interaksi untuk berkomunikasi dengan orang lain, berkomunikasi aktif untuk membicarakan berbagai hal yang salah satunya berkenaan dengan materi pelajaran baik oleh sesama teman maupun dengan guru di sekolah. Dengan keterampilan sosial yang tinggi siswa akan semakin percaya diri dalam mengikuti kegiatan pembelajaran sehingga memungkinkan potensi siswa dalam meraih prestasi yang baik.

Lebih lanjut, siswa hampir setiap hari akan menggunakan gadget smartphone yang mereka miliki. Baik untuk hal yang berhubungan dengan belajar maupun untuk berkomunikasi dengan temannya. Tingkat keseringan siswa dalam menggunakan gadget smartphone yang mereka miliki juga mempengaruh proses belajar siswa. Sehingga siswa yang sering menggunakan gadget smartphone untuk mencari materi-materi cenderung mendapatkan prestasi belajar yang lebih tinggi daripada siswa yang kurang bisa menggunakan gadget smartphone yang mereka miliki.

Berdasarkan hasil penelitian tersebut, maka dapat disimpulkan bahwa semakin tinggi kriteria keterampilan sosial dan penggunaan gadget smartphone siswa SMA Negeri 9 Malang, maka prestasi belajarnya akan semakin meningkat. Hal tersebut ditunjukan dengan adanya hubungan keterampilan sosial siswa dalam berkomunikasi terhadap orang lain (siswa dan guru) mengenai materi pelajaran. Selanjutnya, mengacu pada dampak positif penggunaan gadget smartphone dalam memudahkan siswa mengakses berbagai informasi secara cepat dan akurat yang salah satunya adalah tentang materi pelajaran. Kedua aspek tersebut (keterampilan sosial dan penggunaan gadget smartphone) mempengaruhi siswa SMA Negeri 9 terkait pretasi belajarnya secara positif.

\section{Hubungan Keterampilan Sosial dengan Prestasi Belajar Siswa SMA Negeri 9 Malang}

Dari hasil penelitian yang telah dilakukan dan dianalisa maka didapatkan hasil bahwa terdapat hubungan antara keterampilan sosial dengan prestasi belajar siswa SMA Negeri 9 Malang. Hal ini ditunjukan dengan analisis korelasi menggunakan rumus product moment, diperoleh data nilai koefisien korelasi untuk keterampilan sosial dengan prestasi belajar sebesar $r_{\text {hitung }}=0,442>r_{\text {tabel }} 5 \%=0,312$ dan $\mathrm{p}=0,000<0,05$. Dengan demikian hipotesis penelitian diterima yang berarti adanya hubungan yang signifikan antara keterampilan sosial dengan prestasi belajar. 
Mengacu pada hasil penelitian mengenai hubungan keterampilan sosial dengan prestasi belajar diatas, maka dapat disimpulkan bahwa siswa SMA Negeri 9 Malang yang memiliki keterampilan sosial yang tinggi maka tingkat pretasinya lebih tinggi dibandingkan dengan siswa yang memiliki tingkat keterampilan sosial yang rendah. Terkait hal tersebut, menurut Riggio (dalam Yonatan, 2001) salah satu karakter siswa yang memiliki keterampilan sosial yang tinggi ialah mampu berkomunikasi secara aktif untuk memulai, mengarahkan dan mengakhiri bentuk pembicaraan. Di sisi lain, prestasi merupakan sebuah hasil dari proses belajar siswa yang dalam kegiatannya sarat akan interaksi dan komunikasi.

Siswa SMA Negeri 9 Malang menggunakan keterampilan sosialnya untuk berkomunikasi baik kepada sesama teman dan guru untuk membicarakan hal-hal terkait pelajaran, sehingga siswa yang memiliki keterampilan sosial yang rendah cenderung tidak mampu melakukan interkasi komunikasi pada orang lain salah satunya mengani pelajaran. Hal inilah yang merujuk pada kemapuan sosial siswa berpengaruh pada prestasi belajar.

\section{Hubungan Penggunaan Gadget Smartphone dengan Prestasi Bealajar Siswa SMA Negeri 9 Malang}

Dari hasil penelitian yang telah dilakukan dan dianalisa maka didapatkan hasil bahwa terdapat hubungan antara penggunaan gadget smartphone dengan prestasi belajar siswa SMA Negeri 9 Malang. Hal ini ditunjukan dengan hasil analisis korelasi menggunakan rumus product moment, diperoleh data nilai koefisien korelasi untuk penggunaan gadget smartphone dengan prestasi belajar sebesar $\mathrm{r}_{\text {hitung }}=0,425>\mathrm{r}_{\text {tabel }} 5 \%=0,312$ dan $\mathrm{p}=0,000<0,05$. Dengan demikian hipotesis penelitian diterima yang berarti adanya hubungan yang signifikan antara penggunaan gadget smartphone dengan prestasi belajar.

Siswa yang memiliki gadget smartphone sudah tidak menjadi hal yang aneh lagi. Sebagian besar siswa sekarang tidak lepas dengan gadget smartphone yang mereka miliki. Fitur-fitur dan kemudahan yang ada didalan gadget smartphone sangat memudahkan siswa dalam mendapatkan informasi yang siswa butuhkan ataupun berkomunikasi. Disini siswa bisa mendapatkan semua informasi yang siswa inginkan. Dengan menggunakan gadget smartphone yang dimiliki ini siswa bisa belajar dengan tidak terpaku hanya dengan buku yang siswa miliki saja ataupun belajar dari materi yang diberikan oleh guru saat pelajaran disekolah berlangsung.

Hubungannya dengan materi pelajaran sekolah dimana siswa bisa mencari materi-materi yang sedang dibahas disekolah melalui gadget smartphone yang mereka miliki. Sehingga setelah mendapatkan materi dari guru disekolahnya, siswa bisa menambah pengetahuan ataupun materimateri pelajaran yang mungkin guru mereka belum sempat dijelaskan disekolah dengan menggunakan gadget smartphone yang mereka miliki. Sehingga siswa lebih banyak mendapatkan materi yang bisa menunjang belajar mereka.

\section{SIMPULAN DAN SARAN}

\section{Simpulan}

Berdasarkan analisis dari hasil penelitian yang telah dilakukan, dapat diambil kesimpulan bahwa, keterampilan sosial dan penggunaan gadget smartphone berpengaruh positif terhadap prestasi belajar. Semakin tinggi keterampilan sosial dan penggunaan gadget smartphone maka akan semakin tinggi prestasi belajar siswa. Sebaliknya semakin rendah keterampilan sosial dan penggunaan gadget smartphone maka akan semakin rendah prestasi belajar siswa.

\section{Saran}

Berdasarkan pada hasil penelitian yang dilakukan maka saran yang dapat diajukan oleh peneliti adalah sebagai berikut: (1) Bagi konselor, sebagai bahan kontribusi dan informasi yang berguna untuk menyusun program Bimbingan dan Konseling khususnya pada bidang layanan bimbingan sosial yaitu, 
tentang layanan bimbingan keterampilan sosial dan penggunaan gadget smartphone kepada siswa SMA agar dapat berkembang secara optimal. Bagi peneliti selanjutnya, demi kesempurnaan penelitian diharapkan peneliti selanjutnya dapat menggunakan hasil penelitian ini sebagai referensi atau data tambahan untuk meneliti yang berhubungan dengan keterampilan sosial dan penggunaan gadget smartphone dengan prestasi belajar.

\section{DAFTAR RUJUKAN}

Ameliola, S, Nugraha, D.H. (2013). Perkembangan Media Informasi dan Teknologi Terahadap Anak dalam Era Globalisasi. (Online). (http//icssis.files.wordpress.com), diakses pada: 25 Maret 2016

Blais, 2007. Adolescents Online: The Importance of Internet Activity Choice to Salient Relationships. Journal Youth Adolescence, 37:522-536. (Online). (http://repository.unand.ac.id) Diakses pada: 26 Maret 2016

Indrawan, Pana. (2014). Pengaruh Gadget terhadap Tumbuh Kembang Psiko Sosial Anak PAUD. (Online). (http://library.binus.ac.id). Diakses pada: 25 Maret 2016

Isna, Nadhila. 2012. Mempermudah Hidup Manusia dengan Teknologi Modern.

(Online).(http://komunikasi.us/index.php/mata-kuliah/kmm/12-response-paper-ptk-2013/375mempermudah-hidup-manusia-dengan-teknologi-modern) Diakses pada: 27 Maret 2015

Mubarok, Sulthonul. 2013. Gadget Menjadi Gaya Hidup dan Kebutuhan..(http:// sulthonulmubarok.com/gadget-menjadi-gaya-hidup-dan-kebutuhan), Diakses pada: 7 Januari 2016

Widyastuti, Yani dkk.2009. Kesehatan Reproduksi. Yogyakarta: Fitramaya.

Yonathan, V. 2001. Pengembangan Inventory Keterampilan Sosial Bagi Siswa Sekolah Menengah. Tesis tidak diterbitkan. Malang: Program Pasca Sarjana Universitas Negeri Malang. 